\title{
Vascular Effects of Ginkgo Biloba Extract (EGb-761) on Isolated Human Umbilical Artery Contraction Responses
}

\author{
Ginkgo Biloba Ekstresinin (EGb-761) Izole Insan Umbilikal \\ Arteri Kasılma Yanıtları Üzerine Vasküler Etkileri
}

\author{
Cigdem Gokbas ${ }^{1}$, Ipek Duman²
}

${ }^{1}$ Necmetin Erbakan University, Institute of Health Sciences, Konya, Turkey ${ }^{2}$ Necmetin Erbakan University, Meram

Faculty of Medicine, Department of Medical Pharmacology, Konya, Turkey

Address correspondence to: Ipek Duman, Necmetin Erbakan University, Meram Faculty of Medicine, Department of Medical Pharmacology, Konya, Turkey

e-mail: ipekduman@yahoo.com

Geliş Tarihi/Received: 1 June 2020 Kabul Tarihi/Accepted: 7 November 2020

Öz

Amaç: $\mathrm{Bu}$ in vitro calıșma, EGb-761'in izole insan umbilikal arter üzerindeki vasküler etkilerini ve bu etkilerde nitrik oksit (NO) ve prostaglandinlerin rolünü değerlendirmeyi amaçlamaktadır.

Gereçler ve Yöntem: Umbilikal arter şeritleri, Krebs-Henseleit solüsyonu içeren organ banyolarında asıldı. Uygulanan ajanların oluşturduğu izometrik vazoaktif değişiklikler kaydedildi. Farklı doku gruplarında $(n=9)$ şu deneysel prosedürler yapıldı; 1) Kümülatif uygulanan EGb-761'in umbilikal arter şeritlerinin bazal tonusu üzerindeki etkisi. 2) Kümülatif EGb-761'in 10-6 M 5-HT ile arter şeritlerinde oluşturulan kasılma yanıtı üzerindeki gevşetici etkisi. 3) Kümülatif EGb-761'in L-NAME ile inkübasyon sonrası 5-HT ile arter şeritlerinde oluşturulan kasılma yanıtı üzerindeki gevşetici etkisi 4) Kümülatif EGb-761'in indometazin ile inkübasyon sonrası 5-HT ile arter şeritlerinde oluşturulan kasılma yanıtı üzerindeki gevşetici etkisi ve 5) Kümülatif EGb-761'in L-NAME ve indometazin ile inkübasyonu sonrası 5-HT ile arter şeritlerinde oluşturulan kasılma yanıtı üzerindeki gevşetici etkisi.

Bulgular: Kümülatif EGb-761, 5-HT kaynaklı kasılma cevaplarında konsantrasyona bağlı gevşeme oluşturdu $(p<0.05)$. L-NAME, EGb-761'in tüm konsantrasyonlarında 5-HT kasılmaları üzerinde oluşturduğu gevşeme yanıtlarını önemli ölçüde azalttı $(p<0.05)$. L-NAME, EGb-761'in düşük konsantrasyonlarında oluşturduğu gevşeme yanıtlarını ise tamamen inhibe etti. İndometazin ise bu yanıtları daha yüksek EGb761 konsantrasyonlarında anlamlı şekilde inhibe etti $(p<0.05)$. L-NAME + indometazin, tüm EGb-761 konsantrasyonlarının oluşturduğu yanıtları anlamlı şekilde inhibe etti $(p<0.05)$. L-NAME ve indometazinin birlikte uygulanması, gevşeme yanıtlarında belirli EGb-761 konsantrasyonlarında tek başına L-NAME ve indometazinden daha güçlü bir inhibisyon ile sonuçlandı.

Sonuç: EGb-761'in 5-HT ile önceden kasılma oluşturulan insan umbilikal arter şeritlerine kümülatif olarak uygulanması anlamlı şekilde konsantrasyona bağlı gevşeme yanıtı oluşturmaktadır. NO ve prostaglandinler, bu vazodilatasyon mekanizmasında EGb-761 konsantrasyonuna bağlı olarak değişen potansiyelde katkıda bulunmaktadır.

Anahtar Kelimeler: EGb-761, ginkgo biloba, nitrik oksit, prostaglandin, umbilikal arter, vasküler etki

\begin{abstract}
Aim: This in vitro study assesses the vascular effects of EGb-761 on the isolated human umbilical artery and the role of nitric oxide (NO) and prostaglandins in these effects.

Materials and Methods: Human umbilical artery strips were suspended in organ baths containing KrebsHenseleit solution. Isometric vasoactive changes to the applied agents were recorded. Procedures were conducted in different groups of strips $(n=9) ; 1)$ Effect of cumulative EGb-761 on the basal tonus of the artery. 2) The relaxant effect of cumulative EGb-761 on contraction elicited by 10-6 M 5-HT. 3) Effect of L-NAME incubation on the relaxant effect of cumulative EGb-761 on contraction elicited by 5-HT. 4) Effect of indomethacin incubation on the relaxant effect of cumulative EGb-761 on contraction elicited by 5-HT. 5) Combined effect of L-NAME and indomethacin incubation on the relaxant effect of cumulative EGb-761 on contraction elicited by $5-\mathrm{HT}$.

Results: Cumulative EGb-761 generated concentration-dependent relaxation in 5- $\mathrm{HT}$ induced contraction $(p<0.05)$. L-NAME significantly reduced the relaxation responses at all concentrations of EGb-761 on 5-HT induced contractions $(p<0.05)$. L-NAME completely inhibited relaxation responses of low concentrations of EGb-76. Indomethacin significantly inhibited these responses at higher concentrations of EGb-761 $(p<0.05)$. L-NAME + indomethacin resulted in significant inhibition of relaxation responses with all concentrations of EGb-761 ( $p<0.05)$.

Conclusions: Cumulative application of EGb-761 in human umbilical artery strips precontracted with 5-HT generates significant concentration-dependent relaxation. NO and prostaglandins are involved in the mechanism of vasodilatation with varying potentials depending on the EGb-761 concentration.
\end{abstract}

Key words: EGb-761, Ginkgo biloba, nitric oxide, prostaglandin, umbilical artery, vascular effect

Cite this article as: Gokbas C, Duman I. Vascular Effects of Ginkgo Biloba Extract (EGb-761) on Isolated Human Umbilical Artery Contraction Responses. Selcuk Med J 2021;37(2): 158-165
Disclosure: None of the authors has a financial interest in any of the products, devices, or drugs mentioned in this article. The research was not sponsored by an outside organization. All authors have agreed to allow full access to the primary data and to allow the journal to review the data if requested. 


\section{INTRODUCTION}

Ginkgo biloba is one of the oldest living plant species (1). It is a perennial deciduous tree with bright yellow, two-lobed open and fan-shaped leaves. Ginkgo Biloba leaves and seeds contain many flavonoids and terpenoids used in traditional Chinese medicine for over 5,000 years to treat various illnesses, including asthma, cough, and enuresis. (2). Commercially available extract of the Ginkgo biloba tree (EGb-761) is a standardized mixture that contains flavonoids and terpenoids $(3,4)$. Currently, Ginkgo biloba leaf extracts (GBE) are sold in many countries in the form of filmcoated tablets, oral fluids, and injectable solutions (5). GBE has protective effects on the vascular system due to its ability to scavenge free radicals, inhibit platelet aggregation and inflammation. Furthermore, because of those vasodilatory, antioxidant, and antiplatelet properties as mentioned above, GBE is used to treat ischemic cerebral stroke, Alzheimer's disease, and peripheral vascular diseases (6).

Previous studies show that GBE induces endothelium-dependent vasorelaxation in rat and rabbit aorta and porcine basilar arteries (7-11). However, little information exists regarding the effects of EGb-761 on human fetal and umbilical circulation. Umbilical blood flow is vital for the development of the fetus during pregnancy. It is not innervated; hence umbilical-placental circulation is regulated by the vascular smooth muscle and is controlled solely by the balance between the vasoactive substances that regulate the contractile process (12). Therefore, the direct effects of vasoactive agents on umbilical vessels are crucial for umbilical blood flow. This study was designed to investigate the in vitro effects of Ginkgo biloba extract, EGb-761 on the human umbilical artery's basal tonus and contractions elicited by an endogenous vasoconstrictor, serotonin (5-HT). The study also assesses the role of nitric oxide (NO) and prostaglandins in these effects.

\section{MATERIALS AND METHODS}

The University Human Ethics Committee approved this study (2019/1738). All umbilical cords used in the experiments were remnant tissues, which would have otherwise discarded. With maternal consent, human umbilical cords were collected from healthy full-term normal deliveries. The umbilical cords were transferred to the laboratory in cold Krebs-Henseleit solution (KHS). The umbilical arteries were isolated from surrounding tissues in warm KHS. After being isolated, artery segments were cut into spiral-shaped strips about 2-3 $\mathrm{mm}$ wide and $15 \mathrm{~mm}$ long. The strips were suspended between two stainless steel hooks in $10 \mathrm{ml}$ isolated organ baths containing KHS solution maintained at $37^{\circ} \mathrm{C}$, which was continuously gassed with a mixture of $95 \% \mathrm{O}_{2}-5 \% \mathrm{CO}_{2}$, as described previously (13). In the beginning, the strips were stretched to an initial resting tension of $1 \mathrm{~g}$ and allowed to equilibrate for 60 min in $\mathrm{KHS}$, which was changed every 15 minutes before administering vasoactive drugs.

After the resting period, the following experimental procedures were performed in different groups $(n=9)$, and the vasoactive responses of the applied agents were recorded isometrically (Commat, Ankara, Turkey) via a transducer (BIOPAC MP36, California USA).

\section{Experimental Procedures}

1-Effects of EGb-761 on the basal tonus of umbilical artery strips:

After receiving maximum contraction responses (control) with $10^{-6} \mathrm{M} 5-\mathrm{HT}$, the tissues were washed and rested. Then concentration-response curves were recorded with EGb-761 $(50-500 \mu \mathrm{g} / \mathrm{ml})$ added cumulatively to the organ bath.

\section{2-Effects of EGb-761on contractions elicited by 5-HT:}

Initially, the control contraction responses to $10^{-6} \mathrm{M}$ 5-HT were obtained. After maximum contraction was observed, the strips were subjected to cumulative concentrations of EGb-761 (50-500 $\mu \mathrm{g} / \mathrm{ml})$, and responses were recorded.

\section{3-Effects of NO and prostaglandins on EGb-761 elicited relaxation responses:}

L-NAME: After observing maximum contraction responses in strips contracted with $10^{-6} \mathrm{M} 5-\mathrm{HT}$, the strips were incubated with a NO synthase (NOS) inhibitor N $\omega$-nitro-L-arginine methyl ester (L-NAME, $10^{-4} \mathrm{M}$ ) for 20 minutes before recording the cumulative responses to EGb-761 $(50-500 \mu \mathrm{g} / \mathrm{ml})$.

Indomethacin: Cumulative responses to EGb-761 (50-500 $\mu \mathrm{g} / \mathrm{ml})$ on 10-6 M 5-HT elicited contractions were recorded after the same incubation procedure was repeated with the cyclooxygenase inhibitor indomethacin $\left(10^{-5} \mathrm{M}\right)$.

L-NAME combined with indomethacin: Cumulative responses to EGb-761 $(50-500 \mu \mathrm{g} / \mathrm{ml})$ on $10^{-6} \mathrm{M} 5-\mathrm{HT}$ elicited contractions were recorded after the same incubation procedure was repeated with L-NAME $\left(10^{-4} \mathrm{M}\right)$ combined with indomethacin $\left(10^{-5}\right.$ M)

Krebs-Henseleit solution was prepared in the 
Table 1. Effect of cumulative EGb-761 and the effect of incubation with L-NAME $\left(10^{-4} \mathrm{M}\right)$, indomethacin $(10-5 \mathrm{M})$, and L-NAME $\left(10^{-4} \mathrm{M}\right)+$ indomethacin $\left(10^{-5} \mathrm{M}\right)$ incubation on cumulative EGb-761 elicited relaxation on the contraction responses of 10-6 M 5-HT on the human umbilical artery. Results are the percentage (\%) of contraction responses of 5-HT elicited contraction (control contraction). * $p<0.05$ compared to control contraction, $\ddagger p<0.05$ compared to EGb-761 induced relaxation responses.

\begin{tabular}{|c|c|c|c|c|c|}
\hline & \multicolumn{5}{|c|}{ The cumulative concentration of EGb-761 } \\
\hline & $50 \mu \mathrm{g}$ & $100 \mu \mathrm{g}$ & $200 \mu \mathrm{g}$ & $300 \mu \mathrm{g}$ & $500 \mu g$ \\
\hline EGb-761 & $97.67 \pm 0.81^{*}$ & $95.25 \pm 1.39^{*}$ & $93.12 \pm 1.22^{*}$ & $89.45 \pm 1.94^{*}$ & $84.45 \pm 3.57^{*}$ \\
\hline L-NAME + EGb-761 & $100.0 \pm 0.47 \ddagger$ & $98.66 \pm 1.22 \ddagger$ & $96.99 \pm 1,70^{*} \ddagger$ & $95.46 \pm 1.96^{*} \ddagger$ & $93.05 \pm 2.50 * \ddagger$ \\
\hline Indomethacin + EGb-761 & $98.15 \pm 0.70^{*}$ & $96.70 \pm 1.13^{*}$ & $95.25 \pm 2.20^{*} \ddagger$ & $93.87 \pm 2.26^{*} \ddagger$ & $92.23 \pm 2.70^{*} \ddagger$ \\
\hline L-NAME+ Indomethacin + EGb-761 & $100.0 \pm 0.55 \ddagger$ & $99.70 \pm 0.71 \ddagger$ & $98.37 \pm 0.96 \ddagger$ & $97.24 \pm 1.08^{*} \ddagger$ & $95.96 \pm 1.31^{*} \ddagger$ \\
\hline
\end{tabular}

laboratory with compositions of [mM]: $\mathrm{NaCl} 119$, $\mathrm{KCl} 4.7, \mathrm{KH}_{2} \mathrm{PO}_{4} 1.2, \mathrm{CaCl}_{2} 1.5, \mathrm{MgSO}_{4} 1.2, \mathrm{NaHCO}_{3}$ 25.0, glucose 11, pH:7.4. Ginkgo biloba standardized extract (EGb-761, Ginkobil @) was purchased from Ratiopharm $\mathrm{GmbH}$ (Germany). Serotonin (5-HT), L-NAME, and indomethacin were purchased from Sigma-Aldrich (St. Louis, MO, USA). The drugs used were prepared with distilled water. Each dose was added to the bath in $0.1 \mathrm{ml}$ of volume.

\section{Statistical analysis}

The initial maximum contraction response elicited by $10^{-6} \mathrm{M} 5-\mathrm{HT}$ was considered as control (100\%). In each experimental procedure, responses obtained with cumulative doses of EGb-761 were calculated as a percentage (\%) of the maximum contraction response received with $10^{-6} \mathrm{M}$ 5-HT. For continuous numeric data, arithmetic mean \pm standard deviation (SD) was used to summarize all the normal distribution data. Mixed effect models were used to compare different groups and doses. Data were analyzed using SAS University Edition 9.4. A p-value of less than 0.05 was considered statistically significant.

\section{RESULTS}

5-HT elicited contractions showed no timedependent changes and were reproducible.
Results of the Experimental Procedures 1-Effects of EGb-761 on the basal tonus of umbilical artery strips:

Cumulative EGb-761 (50-500 $\mu \mathrm{g} / \mathrm{ml})$ did not alter the basal tone of the artery strips at any concentration $(P>0.05)$.

2- Effects of EGb-761on contractions elicited by 5-HT:

Cumulative EGb-761 (50-500 $\mu \mathrm{g} / \mathrm{ml})$ generated concentration-dependent relaxation responses after obtaining maximum contraction response with $10^{-6} \mathrm{M}$ $5-\mathrm{HT}$ in umbilical artery strips $(P<0.05)$ (Figures $1-4$, Table 1).

3- Effects of NO and prostaglandins on EGb-761 elicited relaxation responses:

L-NAME: Incubation with $10^{-4} \mathrm{M}$ L-NAME significantly reduced relaxation responses observed with all concentrations of EGb-761 on $10^{-6} \mathrm{M} \mathrm{5-HT}$ induced contractions $(P<0.05)$. L-NAME completely inhibited relaxation responses of low concentrations $(50-100 \mu \mathrm{g} / \mathrm{ml})$ of EGb-761 (Figure 1,4, Table 1).

Indomethacin: Incubation with 10-5 M indomethacin did not alter the relaxation responses generated by lower concentrations of EGb-761(50$100 \mu \mathrm{g} / \mathrm{ml}$ ) on $10^{-6} \mathrm{M} 5-\mathrm{HT}$ induced contractions (P $>0.05)$, while significantly inhibited these responses

Table 2. Comparison of the effects of incubation with L-NAME (10-4 M) + indomethacin (10-5 M) with the results of L-NAME (10-4 M) or indomethacin (10-5 M) separately on relaxation responses elicited by cumulative EGb-761 on the precontracted human umbilical artery. Results are the percentage (\%) of contraction responses of 10-6 M 5-HT elicited contraction (control contraction). ${ }^{*} p<0.05$ compared to indomethacin, $\ddagger \mathrm{p}<0.05$ compared to L-NAME

\begin{tabular}{llllll}
\hline & & \multicolumn{4}{l}{ The cumulative concentration of EGb-761 } \\
& $\mathbf{5 0 \mu}$ & $\mathbf{1 0 0 \mu \mathbf { g }}$ & $\mathbf{2 0 0} \boldsymbol{\mu g}$ & $\mathbf{3 0 0 \mu \mathbf { g }}$ & $\mathbf{5 0 0} \boldsymbol{\mu g}$ \\
\hline L-NAME + EGb-761 & $100.0 \pm 0.47$ & $98.66 \pm 1.22$ & $96.99 \pm 1,70$ & $95.46 \pm 1.96$ & $93.05 \pm 2.50$ \\
Indomethacin + EGb-761 & $98.15 \pm 0.70$ & $96.70 \pm 1.13$ & $95.25 \pm 2.20$ & $93.87 \pm 2.26$ & $92.23 \pm 2.70$ \\
L-NAME+ Indomethacin + EGb-761 & $100.0 \pm 0.55^{*}$ & $99.70 \pm 0.71^{*}$ & $98.37 \pm 0.96^{*}$ & $97.24 \pm 1.08^{*}$ & $95.96 \pm 1.31^{*} \ddagger$ \\
\hline
\end{tabular}


at higher concentrations $(200-500 \mu \mathrm{g} / \mathrm{ml})(P<0.05)$ (Figure 2,4, Table 1).

L-NAMEcombinedwithindomethacin:Incubation with $10^{-4} \mathrm{M} \mathrm{L-NAME}+10^{-5} \mathrm{M}$ indomethacin resulted in significant inhibition of relaxation responses with all concentrations $(50-500 \mu \mathrm{g} / \mathrm{ml})$ of EGb-761 on $10^{-6} \mathrm{M}$ 5 -HT induced contractions $(P<0.05)$. Furthermore, relaxation responses of lower concentrations of EGb$761 \mathrm{up}$ to $200 \mu \mathrm{g}(50-100$ and $200 \mu \mathrm{g}$ ) were inhibited

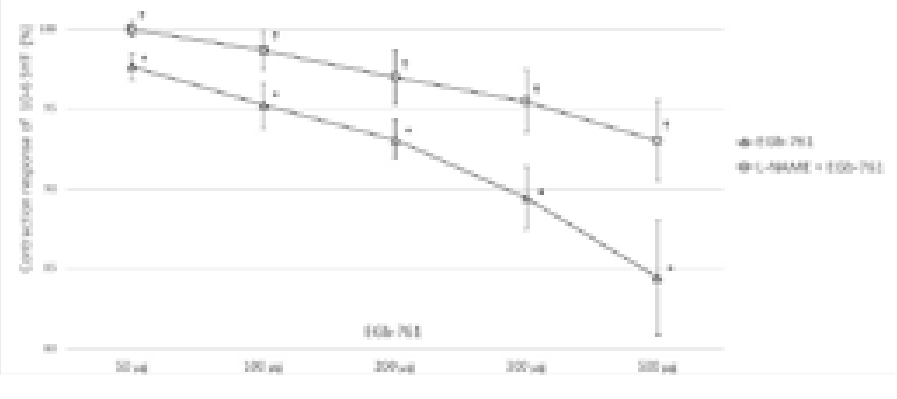

Figure 1. Comparison of the effect of cumulative EGb761 on the contraction responses of 10-6 M 5-HT on the human umbilical artery and the effect of L-NAME incubation on EGb-761 elicited relaxation. Data is presented as the $\%$ of 10-6 M 5-HT elicited control contraction. ${ }^{*} p<0.05$ compared to 10-6 M 5-HT elicited control contraction (100\%), $\ddagger$ p $<0.05$ compared to EGb-761 induced relaxation responses.

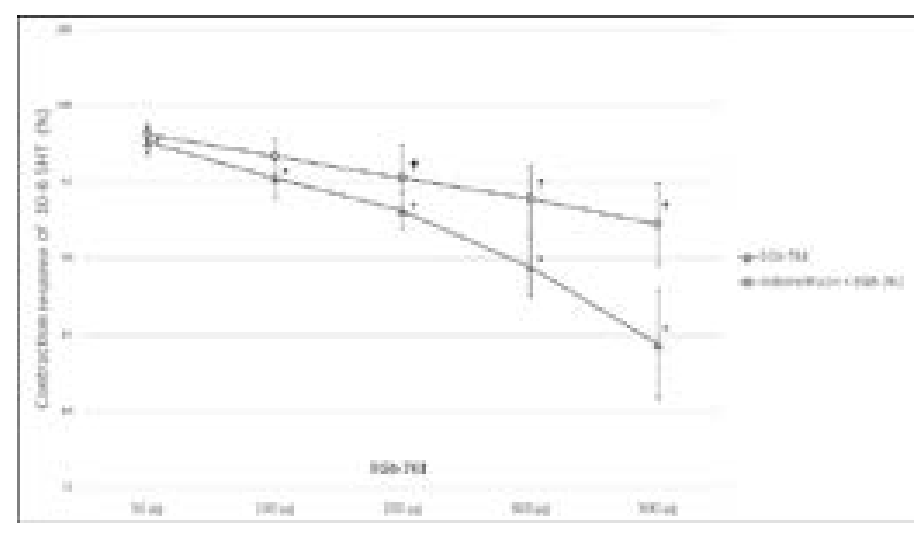

Figure 2. Comparison of the effect of cumulative EGb761 on the contraction responses of 10-6 M 5-HT on the human umbilical artery and the effect of indomethacin incubation on EGb-761 elicited relaxation. Data is presented as the \% of 10-6 M 5-HT elicited control contraction. * $p<0.05$ compared to 10-6 M 5-HT elicited control contraction (100\%), $\neq p<0.05$ compared to EGb-761 induced relaxation responses. completely (Figure 3,4, Table1). When the combined effect of L-NAME + indomethacin incubation on relaxation responses are compared with the results of L-NAME and indomethacin separately, a stronger inhibition on relaxation was observed at the highest concentration $(500 \mu \mathrm{g} / \mathrm{mL})$ of EGb-761 for L-NAME and all concentrations of EGb-761 (100-500 $\mu \mathrm{g} / \mathrm{ml})$ for indomethacin. $(P<0.05)$ (Table 2). The comparison of all cumulative responses of EGb-761(50-500 $\mu \mathrm{g} / \mathrm{ml})$

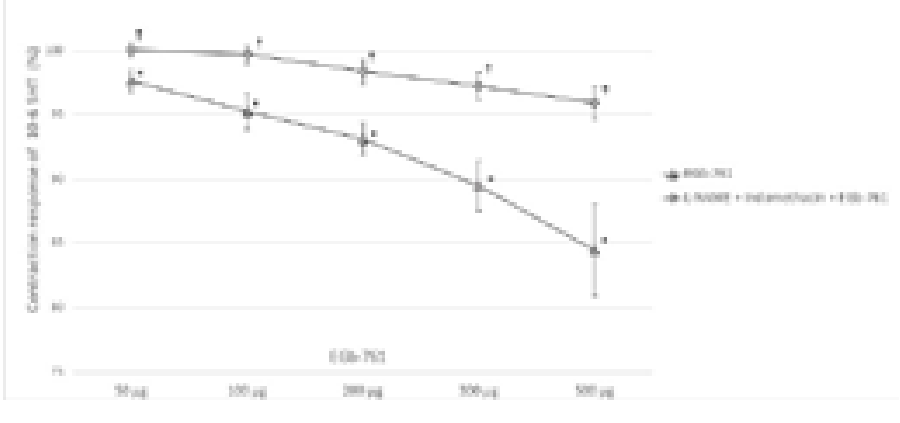

Figure 3. Comparison of the effect of cumulative EGb761 on the contraction responses of 10-6 M 5-HT on the human umbilical artery and the effect of L-NAME + indomethacin incubation on EGb-761 elicited relaxation. Data is presented as the $\%$ of $10-6 \mathrm{M} 5-\mathrm{HT}$ elicited control contraction. ${ }^{*} p<0.05$ compared to 10-6 M 5-HT elicited control contraction (100\%), $\ddagger p<0.05$ compared to EGb-761 induced relaxation responses.

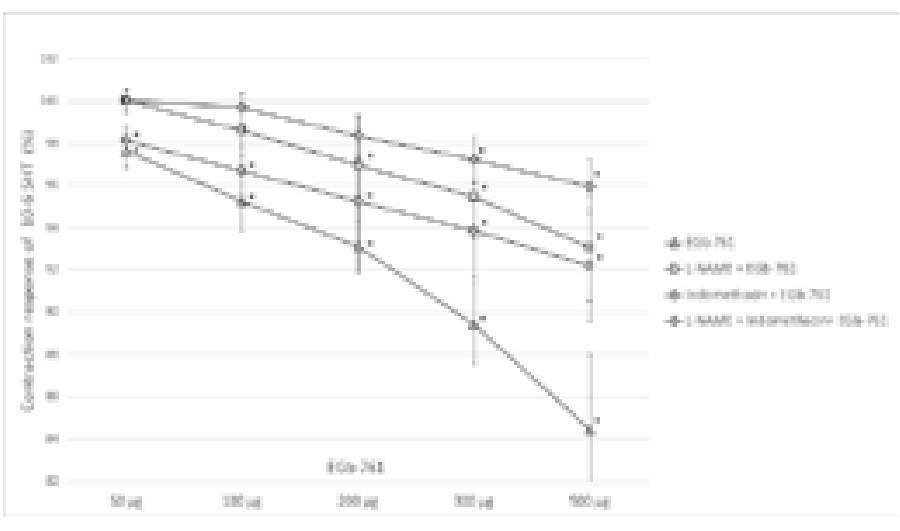

Figure 4. Comparison of all study groups' results with the control contraction responses of 10-6 M 5-HT on the human umbilical artery. Data is presented as the \% of 10-6 M 5-HT elicited control contraction. ${ }^{*} p<0.05$ compared to $10-6 \mathrm{M}$ 5 -HT elicited control contraction (100\%). 
compared to contraction responses elicited with 10-6 M 5-HT in all study groups are shown in figure 4.

\section{DISCUSSIONS}

This study evaluates the vasoactive effects of EGb-761, a standardized extract of Ginkgo biloba in the isolated human umbilical artery. The results show that EGb-761does not alter the arteries' basal tone but elicits dose-dependent vasodilation in umbilical artery strips precontracted with $5-\mathrm{HT}$. NO synthase inhibitor, L-NAME, and prostaglandin inhibitor, indomethacin, decrease the relaxation responses to varying degrees depending on the concentration of EGb-761. Umbilical blood flow is crucial for the development and nutrition of the fetus during pregnancy. Endogenous or exogenous vasoconstrictor and vasodilator substances affecting umbilical vessels provide regulation of umbilicalplacental circulation. Regulation of umbilical vessel flow during pregnancy is achieved mainly by autocrine mechanisms such as humoral vasoactive agents. The endothelial layer of the umbilical vessel contributes to the regulation of vascular smooth muscle tone by producing local vasoconstrictor agents such as endothelin-1 (ET-1) and thromboxane $A_{2}\left(T_{X A}\right)$, as well as vasodilator agents such as prostacyclin $\left(\mathrm{PGI}_{2}\right), \mathrm{NO}$, and endothelium-derived hyperpolarizing factor (EDHF) (12).

EGb-761 is one of the most widely used herbal extracts worldwide. The composition of EGb-761 consists of $24 \%$ flavone glycosides (quercetin, kaempferol, and isorhamnetin) and $6 \%$ terpene lactones (2.8-3.4\% ginkgolides $\mathrm{A}, \mathrm{B}$, and $\mathrm{C}$, and 2.6$3.2 \%$ bilobalide) (7). It is widely consumed as a dietary supplement for preventing and treating cardiovascular diseases and cerebral vascular insufficiency $(4,6,14)$. EGb-761 has been reported to prevent ischemiainduced oxidation, improve cerebral blood flow, and antagonize the effect of platelet-activating factor. EGb761 has been suggested to provide cardiovascular protection due to its antioxidant and anti-platelet activities, improve hemodynamics, and have the potential to reduce the overall cardiovascular disease morbidity and mortality $(4,6)$. Several studies with isolated animal arteries have shown that EGb-761 can reduce vasospasm and induce endotheliumdependent relaxation (8-10). All components of EGb761; both terpenoids and flavonoids contribute more or less to vasodilation in rat aortic rings $(15,16)$. Delaflotte et al. investigated the effects of EGb-761 in the isolated rabbit aorta and found that the effect of
EGb-761 was complicated because of the interactions of the mixture's components. They concluded that the relaxing effect of EGb-761 is partly mediated by factorssuch as NO released from the endothelium (8).

In the present study, the cumulative application of EGb-761on 5-HT elicited contraction resulted in significant relaxation responses in all concentrations. Blocking the endothelium mediated NO pathway with L-NAME resulted in significantly reduced relaxation responses to all concentrations of EGb-761 on 5-HT-induced contractions. Furthermore, complete inhibition occurred at low concentrations $(50-100 \mu \mathrm{g})$ of EGb-761. These findings suggest that NO plays an important role in relaxation responses of EGb-761 in the umbilical artery. Our finding is in accordance with Nishida and Satoh, which investigated the relaxant effects of different components of EGb-761 in rat aortic rings and found that the relaxation is mediated by $\mathrm{NO}$ (15). Also, EGb-761 mediates the relaxation effect of $\mathrm{NO}$ on rabbit aorta and porcine basilar artery $(10,11)$. EGb-761 has been shown to activate NO synthesis by increasing $\mathrm{Ca}^{+2}$ in isolated rat aortic vascular endothelial cells (9). EGb-761 stimulates up-regulation and activation of eNOS protein in endothelial cells, thus leading to enhanced production of NO. Previous results suggest that EGb 761 exhibits dual effects concerning both transcriptional and non-transcriptional activation of eNOS, including activation of the protein kinase Akt and subsequent eNOS phosphorylation. (17)

In rats, the effect of EGb-761 on blood pressure has been studied, and EGb-761 has been reported to reduce systolic blood pressure and increase NO release significantly. It has also been shown that regular daily intake of $120-240 \mathrm{mg}$, representing the standard dose for effective treatment of EGb761 , can increase NO production in vitro and in vivo at concentrations likely to be achieved in the blood $(100 \mu \mathrm{g} / \mathrm{ml})$ (17). Numerous studies have shown that EGb-761 is a multifunctional antioxidant compound that can effectively protect against oxidative stress $(14,18,19)$. In ischemic rats, NO production decreased by $85 \%$ compared to rats that did not receive EGb761 extract (20). EGb-761 has been reported to have free radical cleansing and anti-lipoperoxidation effects that prevent degradation of both $\mathrm{NO}$ and $\mathrm{PGI}_{2}$ (21). It was shown that the vasodilator effects of most flavonoids are, in part, mediated by the release of NO and prostaglandins from the endothelium (22). Our study, while the prostaglandin inhibitor indomethacin did not alter the relaxation responses generated by 
lower concentrations of EGb-761 up to100 $\mu \mathrm{g} / \mathrm{mL}$, showed significant inhibition in these responses at higher concentrations $(200-500 \mu \mathrm{g} / \mathrm{ml})$ of EGB-761. These findings suggest that at higher concentrations of EGb-761, prostaglandins also contribute to the relaxation responses generated by EGb-761.

While incubation of umbilical artery strips with L-NAME and indomethacin combination resulted in significant inhibition on the relaxation elicited by all concentrations of EGb-761, this combination completely inhibited the relaxation responses at lower concentrations of EGb-761, up to $200 \mu \mathrm{g} / \mathrm{mL}$ (50 - 100 and $200 \mu \mathrm{g})$. Furthermore, at certain concentrations of EGb-761, the co-administration of L-NAME and Indomethacin resulted in a more potent inhibition in the observed relaxation responses of EGb-761 than L-NAME and indomethacin alone. It has been shown that COX-2-derived prostaglandins may play a compensatory role as in atherosclerosis in patients with decreased bioavailability of $\mathrm{NO}$; when $\mathrm{NO}$ is blocked, the remaining dilation is due to increased $\mathrm{PGI}_{2}$ synthesis (23). $\mathrm{PGI}_{2}$ facilitates the release of $\mathrm{NO}$ by the endothelial cells $(24,25)$. The effect of PGI2 on the vascular smooth muscle increases indirectly with $\mathrm{NO}(26)$. $\mathrm{PGI}_{2}$ has been reported to show platelet inhibitory effects synergistically with $\mathrm{NO}$ and to inhibit adhesion of leukocytes and vascular smooth muscle proliferation similar to NO (27). Vasodilatory effects of different flavonoids, flavone, naringenin, quercetin, and rutin, were studied in isolated rat aorta. The addition of L-NAME or indomethacin to tissues significantly weakened the inhibitory effects of most flavonoids against phenylephrine-induced contractions; indomethacin incubation significantly reduced the relaxant effects of quercetin and flavone. It was stated that inhibition of $\mathrm{Ca}^{+2}$ flow and release of $\mathrm{Ca}^{+2}$ from intracellular stores are also involved in the vasodilatory effect of flavonoids. (22). Another study showed that vasodilation of EGb-761 extract and its main component bilobalide on rat aortic rings is due to inhibition of $\mathrm{Ca}^{+2}$ current and $\mathrm{NO}$ release activation and maybe partly due to inhibition of $\mathrm{Ca}^{+2}$-activated $\mathrm{K}+$ current and $\mathrm{PGI}_{2}$ release from the endothelium (15). It has been suggested that the effects of Ginkgo biloba on the cardiovascular system are partly mediated through the ion channels (4). Pierre et al. studied the effects of EGb-761on sodium, potassium adenosine triphosphate $\left(\mathrm{Na}^{+}-\mathrm{K}^{+}\right.$-ATPase) activity in the mouse brain, and found that when oral EGb-761was given ten days before the ischemic event protected the $\mathrm{Na}^{+}$ $-\mathrm{K}^{+}$-ATPase activity and reduced lipid peroxidation
(28).

EGb-761 is often used as a complementary therapy in China and European countries to treat hypertension (29). In some in vitro and in vivo studies, EGb-761 extract has been shown to have antihypertensive efficacy and the potential to prevent cardiovascular diseases (30-32). Studies have shown that EGb-761 extract partially reduces the damaged endothelium's thrombogenic properties by inhibiting endothelial activation and adhesion (4). Previous studies indicate that high flavonoid intake has a protective effect on cardiovascular diseases (33). Also, terpenoids in EGb-761 have different biological activities such as peripheral vasoregulation, antagonism of the plateletactivating factor receptor, neuroprotective properties, and membrane damage prevention caused by free radicals (34). Flavonoids and their metabolites can interact with neuronal receptors and modulate gene and protein expression that controls kinase signaling pathways, transcription factors, and memory and learning processes in the hippocampus (35). It can also improve cerebrovascular blood flow and synaptic plasticity, resulting in improved memory and learning and cognitive functions. It has been claimed that some natural flavonoids protect the loss of immune cell function (36). Also, there are related studies which show that flavonoids cause a reduction particularly in TNF- $\alpha$ (tumor necrosis factor- $\alpha$ ), IL-1 $\beta$ (interleukin$1 \beta$ ), prostaglandin E2 and NFkB (nuclear factor kappa-B) signaling through reducing inflammatory cytokine production (37).

As stated above, the interaction between EGb-761 and the vascular endothelium is complex, and there is no consensus on the mechanisms of the vasoactive effects that GBE promotes in vascular tissues of various species. In this study, we investigated the direct vasoactive effects of Ginkgo Biloba extract EGb-761, one of the most widely used herbal remedies in the world, on the umbilical artery and the possible roles of $\mathrm{NO}$ and prostaglandins in these effects. In conclusion, EGb-761 does not affect the basal tone of the human umbilical artery. The cumulative application of EGb761 in human umbilical artery strips precontracted with 5-HT generates significant concentrationdependent relaxation in vascular smooth muscle. NO and prostaglandins are involved in the mechanism of vasodilatation with varying potentials depending on the EGb-761 concentration. Prostaglandins also create synergy with $\mathrm{NO}$ in these responses. Further research is needed to elucidate the effects of EGb761 on contractions of different vasoconstrictor 
agents and the involved mechanisms.

Conflict of interest: Authors declare that there is no conflict of interest between the authors of the article.

Financial conflict of interest: Authors declare that they did not receive any financial support in this study.

Address correspondence to: Ipek Duman, Necmetin Erbakan University, Meram Faculty of Medicine, Department of Medical Pharmacology, Konya, Turkey

e-mail: ipekduman@yahoo.com

\section{REFERENCES}

1. Pinto MDS, Kwon YI, Apostolidis E, et al. Potential of Ginkgo biloba $L$. leaves in the management of hyperglycemia and hypertension using in vitro models. Bioresour Technol 2009;100(24):6599-609.

2. Bilia AR. Ginkgo biloba L. Fitoterapia 2002;73(3):276-9.

3. Singh SK, Srivastav S, Castellani RJ, et al. Neuroprotective and antioxidant effect of Ginkgo biloba extract against $A D$ and other neurological disorders. Neurotherapeutics 2019;16(3):666-74.

4. Zhou, W, Chai H. Lin PH, et al. Clinical use and molecular mechanisms of action of extract of Ginkgo biloba leaves in cardiovascular diseases. Cardiovasc Drug Rev 2004;22(4):309-19.

5. Chan PC, Xia QS, Fu PP. Ginkgo biloba leave extract: Biological, medicinal, and toxicological effects. J Environ Sci Health C Environ Carcinog Ecotoxicol Rev 2007;25(3):21144.

6. Tian J, Liu Y, Chen K. Ginkgo biloba extract in vascular protection: molecular mechanisms and clinical applications, Curr Vasc Pharmacol 2017;15:532-48.

7. $E G b$ 761: ginkgo biloba extract, Ginkor. Drugs $R \quad D$ 2003;4(3):188-93.

8. Delaflotte S, Auguet M, DeFeudis F, et al. Endotheliumdependent relaxations of rabbit isolated aorta produced by carbachol and by Ginkgo biloba extract. Biomed Biochim Acta 1984;43(8-9):S212-6.

9. Kubota $\mathrm{Y}$, Tanaka N, Umegaki K, et al. Ginkgo biloba extract-induced relaxation of rat aorta is associated with increase in endothelial intracellular calcium level. Life Sci 2001;69(20):2327-36.

10. Chen X, Salwinski S, Lee TF. Extracts of Ginkgo biloba and ginsenosides exert cerebral vasorelaxation via a nitric oxide pathway. Clin Exp Pharmacol Physiol 1997;24(12):958-9.

11. Chen X, Liu L, Li Z. Cardiovascular protective effects and NOmediated cerebrovasorelaxant effects of extract of Ginkgo biloba leaves. Zhonghua Yi Xue Za Zhi 1998;78(9):692-5.

12. Lorigo $M$, Mariana $M$, Feiteiro $J$, et al. How is the human umbilical artery regulated? J Obstet Gynaecol Res 2018;44(7):1193-201.

13. Dagtekin E, Sahin AS. Effects of leptin on hydrogen peroxide induced contractions in isolated human umbilical artery. Selcuk Med J 2018;34(4):160-4.

14. Coyoy-Salgado A, Segura-Uribe JJ, Guerra-Araiza C, et al. The importance of natural antioxidants in the treatment of spinal cord injury in animal models: An overview. Oxid Med Cell Longev 2019;2019:3642491.

15. Nishida S, Satoh H. Mechanisms for the vasodilations induced by Ginkgo biloba extract and its main constituent, bilobalide, in rat aorta, Life Sci 2003;72(23):2659-67.

16. Nishida S, Satoh $\mathrm{H}$. Comparative vasodilating actions among terpenoids and flavonoids contained in Ginkgo biloba extract. Clin Chimi Acta 2004;339(1-2):129-33.

17. Koltermann A, Hartkorn A, Koch E, et al. Ginkgo biloba extract $E G b ® 761$ increases endothelial nitric oxide production in vitro and in vivo. Cellular and Molecular Life Sciences 2007;64(13):1715-22.

18. Zhang S, Yi X, Su X, et al. Ginkgo biloba extract protects human melanocytes from $\mathrm{H} 2 \mathrm{O} 2$ induced oxidative stress by activating Nrf2. J Cell Mol Med 2019;23(8):5193-9.

19. Mohamed NE, Abd El-Moneim AE. Ginkgo biloba extract alleviates oxidative stress and so neurotransmitters changes induced by aluminum chloride in rats. Nutrition 2017;35:93-9.

20. Varga $E$, Bodi $A$, Ferdinandy $P$, et al. The protective effect of EGb 761 in isolated ischemic/reperfused rat hearts: $A$ link between cardiac function and nitric oxide production. $J$ Cardiovasc Pharmacol 1999;34(5):711-7.

21. Dziwenka M, Coppock RW. Ginkgo biloba. In: Nutraceuticals: Prospects and Perspectives. Amsterdam: Elsevier, 2016: 681-91.

22. Ajay M, Gilani AU, Mustafa MR. Effects of flavonoids on vascular smooth muscle of the isolated rat thoracic aorta. Life Sci 2003;74(5):603-12.

23. Szerafin T, Erdei N, Fülöp T, et al. Increased cyclooxygenase-2 expression and prostaglandin-mediated dilation in coronary arterioles of patients with diabetes mellitus. Circ Res 2006;99(5):e12-7.

24. Shimokawa H, Flavahan NA, Lorenz RR, et al. Prostacyclin releases endothelium-derived relaxing factor and potentiates its action in coronary arteries of the pig. $\mathrm{Br} J$ Pharmacol 1988;95(4):1197-203.

25. Russell-Puleri S, Dela Paz NG, Adams D, et al. Fluid shear stress induces upregulation of $\mathrm{COX}-2$ and $\mathrm{PGI} 2$ release in endothelial cells via a pathway involving PECAM-1, PI3K, FAK, and p38. Am J Physiol Heart Circ Physiol 2017;312(3):H485-500.

26. Delpy E, Coste H, Gouville AC. Effects of cyclic GMP elevation on isoprenaline-induced increase in cyclic AMP and relaxation in rat aortic smooth muscle: Role of phosphodiesterase $3 . \mathrm{Br}$ J Pharmacol 1996;119(3):471-8.

27. Radomski MW, Palmer RM, Moncada S. Comparative pharmacology of endothelium-derived relaxing factor, nitric oxide and prostacyclin in platelets. $\mathrm{Br} \mathrm{J}$ Pharmacol 1987;92(1):181-7.

28. Pierre S, Jamme I, Droy-Lefaix MT, et al. Ginkgo bilobaextract (EGb 761) protects $\mathrm{Na}, \mathrm{K}-\mathrm{ATP}$ ase activity during cerebral ischemia inmice. Neuroreport 1999;10(1):47-51.

29. Xiong $X J$, Liu W, Yang $X C$, et al. Ginkgo biloba extract for essential hypertension: A systemic review. Phytomedicine 2014;21(10):1131-6.

30. Kudolo GB, Dorsey S, Blodgett J. Effect of the ingestion of Ginkgo biloba extract on platelet aggregation and urinary prostanoid excretion in healthy and Type 2 diabetic subjects. Thromb Res 2002;108(2-3):151-60.

31. Sasaki Y, Noguchi T, Yamamoto E, et al. Effects of Ginkgo biloba extract (EGb 761) on cerebral thrombosis and blood pressure in stroke-prone spontaneously hypertensive rats. Clin Exp Pharmacol Physiol 2002;29(11):963-7.

32. Zhang J, Fu S, Liu S, et al. The therapeutic effect of Ginkgo biloba extract in SHR rats and its possible mechanisms 
based on cerebral microvascular flow and vasomotion. Clin Hemorheol Microcirc 2000;23(2-4):133-8.

33. Kim Y, Je Y. Flavonoid intake and mortality from cardiovascular disease and all causes: A meta-analysis of prospective cohort studies. Clin Nutr ESPEN 2017;20:68-77.

34. Huang $P$, Zhang $L$, Chai $C$, et al. Effects of food and gender on the pharmacokinetics of ginkgolides A, B, C and bilobalide in rats after oral dosing with ginkgo terpene lactones extract. J Pharm Biomed Anal 2014;100:138-44.

35. Rendeiro C, Guerreiro JD, Williams CM, et al. Flavonoids as modulators of memory and learning: Molecular interactions resulting in behavioural effects. Proc Nutr Soc 2012;71(2):246-62.
36. Rubio-Perez JM, Morillas-Ruiz JM. A review: Inflammatory process in Alzheimer's disease, role of cytokines. Scientific World Journal 2012;2012:756357.

37. Ude C, Schubert-Zsilavecz M, Wurglics M. Ginkgo biloba extracts: A review of the pharmacokinetics of the active ingredients. Clin Pharmacokinet 2013;52(9):727-49. 